Regular Paper

\title{
Saccharide and Fructooligosaccharide Contents, and Invertase, 1-KHE, 1-SST, 1-FFT and 6G-FFT Activities in Green Asparagus Spears during Storage: Effects of Temperature and Spear Portion
}

\author{
(Received January 15, 2007; Accepted April 4, 2007)
Norio Shiomi, ${ }^{1, *}$ Noureddine Benkeblia, ${ }^{1}$ Shuichi Onodera, ${ }^{1}$ Toshima Omori, ${ }^{1}$ Natsuko Takahashi, ${ }^{1}$ Masaki Fujishima, ${ }^{1}$ Taiki Yoshihira ${ }^{2}$ and Shinichi Kosaka ${ }^{2}$ \\ ${ }^{1}$ Department of Food and Nutrition Sciences and ${ }^{2}$ Department of Dairy Science, Graduate School of Dairy Science Research, \\ Rakuno Gakuen University, (582, Bunkyodai, Midorimachi, Ebetsu 069-8501, Japan)

\begin{abstract}
Fresh spears of asparagus were stored in the dark at 4,10 or $20^{\circ} \mathrm{C}$ for 2 weeks. During storage contents of glucose, fructose, sucrose, 1-kestose, neokestose and nystose, and activities of invertase, 1-kestose hydrolyzing enzyme (1-KHE), sucrose: sucrose 1-fructosyltransferase (1-SST), fructan: fructan 1fructosyltransferase (1-FFT) and fructan: fructan $6^{\mathrm{G}}$-fructosyltransferase (6G-FFT) were determined in the top, middle and bottom portions of the spears. A gradient was observed, from the bottom to the top, for glucose, fructose and sucrose which constitute the major proportion of carbohydrates, while fructooligosaccharides, neokestose and nystose, exhibited low levels. Glucose and fructose varied significantly during storage, while sucrose was stable. The average variations were from 7.8 to $12.21 \mathrm{mg} / \mathrm{g} \mathrm{FW}$ in the middle portion and 7.88 to $13.52 \mathrm{mg} / \mathrm{g} \mathrm{FW}$ in the bottom portion for glucose and fructose, respectively. 1-Kestose and nystose increased at the end of the storage period and this increase was more apparent at $20^{\circ} \mathrm{C}$. Invertase activity showed similar variation at 4 and $10^{\circ} \mathrm{C}$ but increased sharply after 2 days, before decreasing abruptly after 1 week of storage, while 1-kestose hydrolyzing activity showed a similar pattern to that of invertase activity. 1SST did not vary in the bottom portion but initially increased in the middle and top portions. 1-FFT was high in the top portion and decreased during storage, while in the middle and bottom portions its activity varied slightly. The variation of 6G-FFT activity was similar to that of 1-FFT, however, the level of 6G-FFT was higher, and the 6G-FFT to 1-FFT activity ratio was temperature independent. These results suggest that short fructooligosaccharides and their metabolizing enzymes could play a role of balance between the hydrolysis and synthesis activities of carbohydrates. The high content of sugars may also extend the rapid decline of sugars in the top portion of the spears.
\end{abstract}

Key words: sugars, fructooligosaccharides, asparagus, storage

Unlike most vegetable crops, asparagus, a hardy perennial plant, is commonly consumed and appreciated because it is low in calories and provides substantial amounts of reducing sugars and a very low amount of fructooligosaccharides (FOS), and these fructosyl polymers are well known for their health benefits. ${ }^{1)}$ The chemical characteristics of the spears are markedly affected by temperature, ${ }^{2)}$ growth conditions ${ }^{3)}$ and harvest date. ${ }^{4)}$ Carbohydrates are major constituents of asparagus spears and contribute considerably to their quality. ${ }^{1)}$ The main carbohydrates in asparagus spears are glucose, fructose and sucrose, ${ }^{2,4)}$ while the presence of FOS has never been reported. In asparagus carbohydrates are translocated from storage roots to spears, where they are hydrolyzed into hexoses and used during the catabolic activities of the spears. ${ }^{4}$ Thus, soluble carbohydrate levels decline particularly during the first hours after harvest, and this decline triggers deterioration in the spears. ${ }^{5,6}$ While little FOS are

${ }^{*}$ Corresponding author $($ Tel. $+81-11-388-4754$, Fax. $+81-11-387-$ 5848, E-mail: n-shiomi@ rakuno.ac.jp).

Abbreviations: 1-SST, sucrose: sucrose 1-fructosyltransferase; 1FFT, fructan: fructan 1-fructosyltransferase; 6G-FFT, fructan: fructan $6^{\mathrm{G}}$-fructosyltransferase; 1-KHE, 1-kestose hydrolyzing enzyme; $\mathrm{sFOS}$, short fructooligosaccharides. detected in aerial parts of asparagus, it remains still unclear the reason for the difference of FOS content between the top and the bottom parts of the spears. On the other hand, the role of FOS in spears tissues is also unknown. It is not clear if their presence results from simple translocation from roots to spears to provide energetic substrates, or whether they are translocated to play specific roles such as osmoregulation, or to partially compensate for the rapid decline of sucrose in tips.

Numerous investigations have been carried out on the structures, ${ }^{7-11)}$ enzymology $^{12)}$ and molecular biology ${ }^{13)}$ of FOS in roots of asparagus and such research works were recently reviewed by Shiomi et al. ${ }^{14)}$ but there have been no reports on their presence in aerial tissues. Although many studies have focused on the carbohydrate content of edible spears after harvesting, few studies have focused on soluble and reducing sugars, including soluble invertase, while no investigations have been carried out on FOS and their metabolizing enzymes in asparagus spears.

From the technological point of view, freshly harvested spears deteriorate rapidly at ambient temperatures, ${ }^{1)}$ and have a short shelf-life, which is strongly related to respiratory activity. ${ }^{15)}$ This postharvest deterioration is accompanied by biochemical changes, particularly in spear tips 
where soluble carbohydrates, such as sucrose, decline rapidly. $^{16)}$

The objective of this study was to qualitatively and quantitatively investigate the variation of carbohydrates, including FOS and their related metabolizing enzymes, in different portions of green asparagus spears during storage at different temperatures.

\section{MATERIALS AND METHODS}

Plant material. Fresh spears of asparagus (cv. HLA7) were obtained from an experimental field of Yotei Farmers' Cooperative, Hokkaido, Japan. The spears of 20$22 \mathrm{~cm}$ length were manually harvested, sorted for absence of defects, slightly rinsed with tap water and left for $2 \mathrm{~h}$ at room temperature to drain residual water.

Storage conditions. Asparagus spears were stored in the dark under three different temperature regimes. For the low temperature regimes, spears were placed in a refrigerated chamber (Eyelatron, model FLI $301 \mathrm{NH}, \mathrm{Ri}-$ kakikai Co., Ltd., Tokyo) at $4 \pm 0.1{ }^{\circ} \mathrm{C}$ and $65 \pm 1 \%$ relative humidity (RH), and $10 \pm 0.1^{\circ} \mathrm{C}$ and $55 \pm 1 \% \mathrm{RH}$. For the high temperature regime, $20^{\circ} \mathrm{C}$, spears were placed in a ventilated room with an average RH of $50 \%$. The relative humidities are set according to the storage practices recommended for vegetables.

Saccharides and fructooligosaccharides extraction. Saccharides and fructooligosaccharides (FOS) were extracted by the method of Shiomi. ${ }^{17)}$ Tissues $(10 \mathrm{~g})$ were homogenized in $80 \mathrm{~mL}$ of aqueous ethanol (70\%) using a small amount of calcium carbonate $(0.5 \mathrm{~g} / \mathrm{L})$. The homogenate was boiled under reflux in a water bath for 10 min. Homogenate was filtered and the residue was extracted three times with aqueous ethanol and one time with water under the same conditions. The filtrates were combined and made up to $500 \mathrm{~mL}$ with distilled water. An aliquot of the filtrate $(10 \mathrm{~mL})$ was concentrated to dryness under vacuum at $35^{\circ} \mathrm{C}$ using a Büchi rotavapor (Büchi Labortechnik AG, Flawil, Switzerland). This dry concentrate was redissolved in $1 \mathrm{~mL}$ of water, filtered through a $0.45 \mu \mathrm{m}$ filter and analyzed by high performance anion exchange chromatography (HPAEC Dionex, Sunnyvale, CA, USA). All processes were run in triplicate.

Saccharides and Fructooligosaccharides analysis. Glucose, fructose, sucrose and FOS (1-kestose, neokestose and nystose) were separated on an HPLC-carbohydrate column PA1, Carbo Pack (Sunnyvale, CA, USA) with a Dionex Bio LC series HPLC (Sunnyvale, CA, USA) and pulsed amperometric detector (PAD). The gradient was established by mixing eluent $\mathrm{A}(150 \mathrm{mM} \mathrm{NaOH})$ with eluent $\mathrm{B}(500 \mathrm{mM}$ acetate- $\mathrm{Na}$ in $150 \mathrm{mM} \mathrm{NaOH})$ in two ways. System I: 0-1 min, $25 \mathrm{mM}$; 1-2 $\mathrm{min}, 25-50 \mathrm{mM}$; 2-20 min, 50-200 mM, 20-22 min, 500 mM; 22-30, $25 \mathrm{~mm}$. System II: 0-1 min, $25 \mathrm{~mm}$; 1-2 $\mathrm{min}, 25-50 \mathrm{~mm}$; 2-14 min, 50-500 mM, 14-22 min, 500 mm; 22-30, 25 $\mathrm{mM}$. The established gradient of mixing eluent $\mathrm{A}$ with eluent $\mathrm{B}$ was: $0-1 \mathrm{~min}, 95 \% \mathrm{~A}-5 \% \mathrm{~B} ; 1-2 \mathrm{~min}, 80 \% \mathrm{~A}-20 \%$ $\mathrm{B} ; 2-20 \mathrm{~min}, 60 \% \mathrm{~A}-40 \% \mathrm{~B} ; 20-22 \mathrm{~min}, 100 \% \mathrm{~B}$, 22-30 min, $95 \% \mathrm{~A}-5 \% \mathrm{~B}$. The flow rate through the column was $1.0 \mathrm{~mL} \mathrm{~min}{ }^{-1}$. The applied PAD potentials for E1 (500 ms), E2 (100 ms) and E3 (50 ms) were 0.01, 0.60 and $-0.60 \mathrm{~V}$ respectively, and the output range was $1 \mu \mathrm{C}$. Samples $(25 \mu \mathrm{L})$ were injected using an auto-sampler (Intelligent Auto-sampler, model AS-4000, HITACHI Ltd., Tokyo, Japan). FOS are estimated by comparison with standards peaks and expressed in $\mathrm{mg}$ per gram fresh weight $(\mathrm{mg} / \mathrm{g} \mathrm{FW})$.

Glucose, fructose and sucrose standards were purchased from Nacalai Tesque, Inc. (Kyoto, Japan). 1-Kestose [3a, $1^{\mathrm{F}}$ - $\beta$-D-fructofuranosylsucrose, 1-kestotriose] and nystose [4a, $1^{\mathrm{F}}$ (1- $\beta$-D-fructofuranosyl $)_{2}$ sucrose, 1,1-kestotetraose] were previously prepared in the laboratory as described by Takeda et $a l .{ }^{18)}$ Neokestose [3b, $6^{\mathrm{G}}-\beta$-D-fructofuranosyl sucrose, $6^{\mathrm{G}}$-kestotriose] and $1^{\mathrm{F}}, 6^{\mathrm{G}}$-di- $\beta$-D-fructofuranosyl sucrose, [4c, 1, $6^{\mathrm{G}}$-kestotetraose] were obtained from asparagus roots as described previously by Shiomi et al. . $^{\text {. }}$

Enzyme extraction. All operations of enzyme extraction were carried out on ice. The asparagus tissues (10 g) were homogenized in $20 \mathrm{~mL}$ of ice-cold phosphate buffer (0.01 M, pH 7.0) using a blender (model IFM-140, Iwatani Int. Corp., Tokyo, Japan). The homogenate was squeezed through three layers of cheesecloth, filled up to $30 \mathrm{~mL}$ with distilled water and centrifuged at $15,000 \times g$ at $0^{\circ} \mathrm{C}$ for $30 \mathrm{~min}$. The supernatant was then collected and dialyzed for $48 \mathrm{~h}$ against the same phosphate buffer using cellulose tubing. The dialysate was concentrated to a final volume of $5 \mathrm{~mL}$ by centrifugation $(3,000 \times g)$ using an Amicon Centriprep YM 10 filter (Amicon Bioseparation, Millipore, Bedford, Mass., USA). This enzyme extract was used for enzyme assays.

Assay of 1-SST and invertase activities. One unit of SST activity was defined as the amount of enzyme which catalyzed fructosyl transfer from sucrose to sucrose to produce $1 \mu \mathrm{mol}$ of 1-kestose (3a) in 1 min under the conditions described below. A mixture of enzyme extract $(400 \mu \mathrm{L}), 0.4 \mathrm{M}$ sucrose solution $(200 \mu \mathrm{L})$, McIlvaine buffer pH $5.5(200 \mu \mathrm{L})$ and a trace amount $(\sim 50 \mu \mathrm{L})$ of toluene, was incubated at $30^{\circ} \mathrm{C}$ for $3 \mathrm{~h}$. The reaction was stopped by heating in a boiling water bath for $3 \mathrm{~min}$, and the mixture was analyzed by HPAEC-PAD as described above.

One unit of invertase activity was defined as the amount of enzyme which hydrolyzed $1 \mu \mathrm{mol}$ of sucrose in $1 \mathrm{~min}$. The experimental conditions were those described for SST measurements. Invertase activity was calculated from the amount of fructose released and analyzed by HPAEC as described above.

Assay of 1-FFT, 6G-FFT and 1-KHE activities. One unit of 1-FFT activity was defined as the amount of the enzyme which catalyzed the fructosyl transfer from 1kestose to another 1-kestose to synthesize $1 \mu \mathrm{mol}$ of nystose (4a) in 1 min under the conditions described below. A mixture of enzyme ( $400 \mu \mathrm{L}), 0.4 \mathrm{M} 1$-kestose solution $(200 \mu \mathrm{L})$ and McIlvaine buffer ( $\mathrm{pH}$ 5.5, $200 \mu \mathrm{L}$ ) was incubated at $30^{\circ} \mathrm{C}$ for $3 \mathrm{~h}$. The reaction was stopped by heating in boiling water. The activity of 1-FFT was calculated from the amount of nystose formed.

One unit of 6G-FFT activity was defined as the amount of the enzyme which catalyzed the fructosyl transfer from 1-kestose to another 1-kestose to synthesize $1 \mu \mathrm{mol}$ of $1^{\mathrm{F}}$, $6^{\mathrm{G}}$-di- $\beta$-D-fructofuranosyl sucrose $\left[\mathbf{4 c}, 1,6^{\mathrm{G}}\right.$-kestotetraose] 
in $1 \mathrm{~min}$. The activity of 6G-FFT was tested using the mixture for 1-FFT assay, and calculated from the amount of $1,6^{\mathrm{G}}$-kestotetraose formed.

One unit of 1-KHE activity was defined as the amount of enzyme which hydrolyzed $1 \mu \mathrm{mol}$ of 1-kestose in 1 min. The experimental conditions were those described for 1-FFT measurements. 1-Kestose hydrolyzing activity was calculated from the amount of fructose released and analyzed by HPAEC as described above.

Statistical analysis. The analyses were run in triplicate and the experiment was conducted in duplicate. The data were analyzed statistically by comparison of means by a one-way ANOVA test and determination of least significant difference ( $L S D$ at $p=0.05)$ using GraphPad Instat 3.06 (GraphPad Software Inc., San Diego, CA, USA).

\section{RESULTS}

Sugar analysis by HPAEC-PAD confirmed that glucose, fructose and sucrose constitute the major part of the total soluble sugars in green asparagus. Glucose, fructose and sucrose averaged 33.56, 51.97 and $13.31 \%$ respectively, while low DP fructooligosaccharides (FOS), 1-kestose, neokestose and nystose averaged $0.80,0.20$ and $0.18 \%$, respectively.

At $4{ }^{\circ} \mathrm{C}$, glucose content showed little variation in the top portion and increased slightly but not significantly in the middle and bottom portions although their content was higher than that of the top portion (Fig. 1A). At $10^{\circ} \mathrm{C}$, the difference between the top and the two other portions was less than that observed at $4^{\circ} \mathrm{C}$, and the content of all portions varied slightly during the storage period. In contrast, at $20^{\circ} \mathrm{C}$, although a similar difference was observed between the top and other portions, glucose content decreased during the last week of storage and this decrease was due to the high metabolic rate at this temperature.

Fructose content showed a similar pattern to glucose even though the increase observed in the middle and bottom portions at $4{ }^{\circ} \mathrm{C}$ was significant and this was due to the low metabolic activity in these two portions (Fig. 1B). We also noted that fructose content at $10^{\circ} \mathrm{C}$ was maintained in a steady-state, while at $20^{\circ} \mathrm{C}$ it decreased significantly in these two portions.

In contrast, sucrose content exhibited a specific pattern with a slight increase observed at 4 and $10^{\circ} \mathrm{C}$, while its content was stable at $20^{\circ} \mathrm{C}$ (Fig. 1C). Except at $10^{\circ} \mathrm{C}$, where the sucrose content of the top portion was higher, no difference was noted between the portions at the three temperature regimes.

The content of 1-kestose also showed a specific pattern. At 4 and $10^{\circ} \mathrm{C}$, its content was low and increased significantly during the second week of storage (Fig. 2A). At 20 ${ }^{\circ} \mathrm{C}$, 1-kestose content began increasing after 4 days of storage and this increase was greater than that observed at 4 and $10^{\circ} \mathrm{C}$ and the difference between the portions was significant during the last week of storage. The lowest content was observed in the bottom portion at 4 and $20^{\circ} \mathrm{C}$, while no change was observed in the middle portion at 10 ${ }^{\circ} \mathrm{C}$. It was also noted that 1 -kestose content was positively correlated to fructose released, particularly at $20^{\circ} \mathrm{C}$.
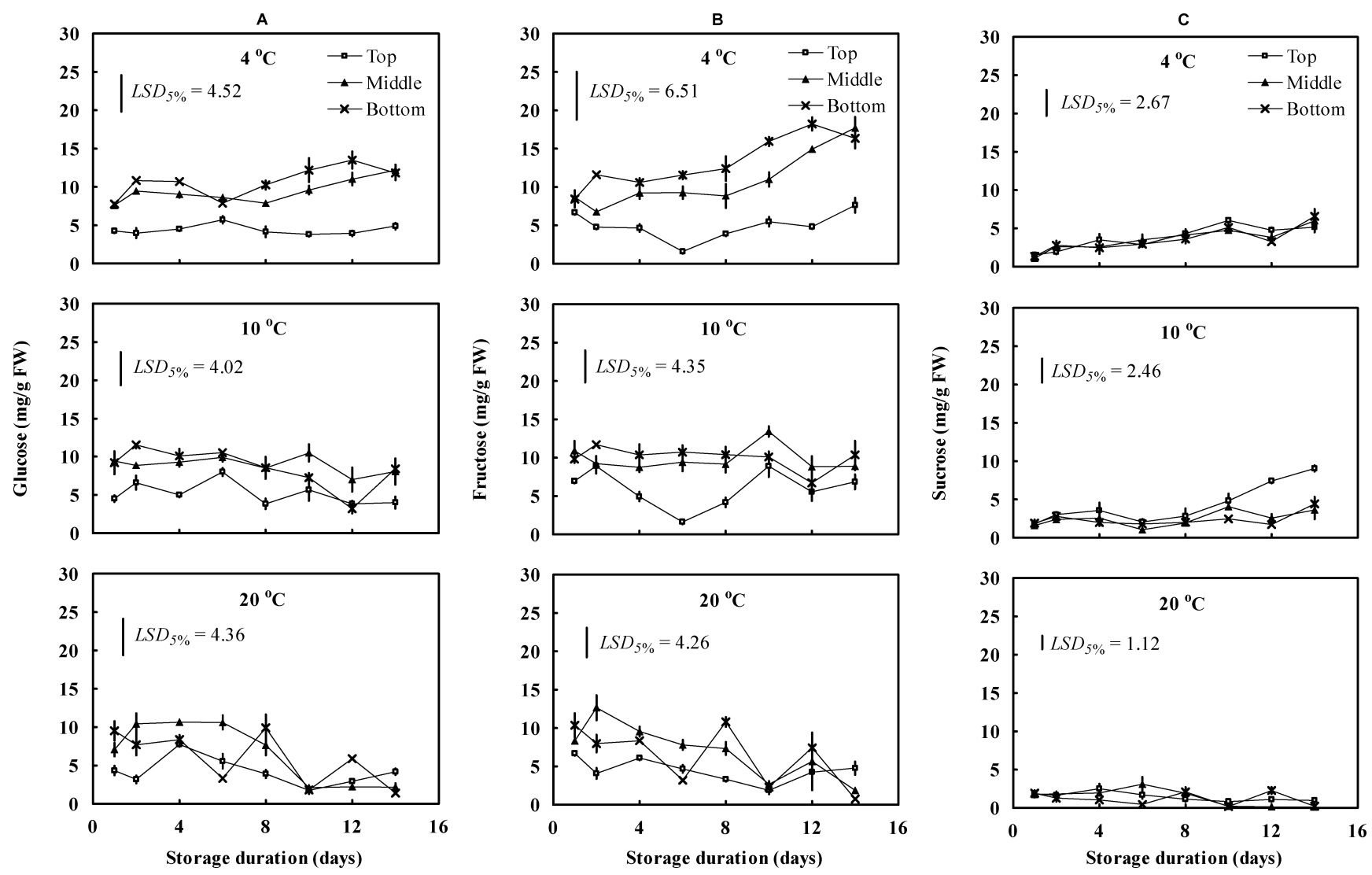

Fig. 1. Variation of glucose (A), fructose (B) and sucrose (C) contents in the top, middle and bottom portions of asparagus spears stored at different temperatures.

Vertical bars represent \pm SD of $n=6$ and LSD was calculated at $p=0.05$. 
The variation of neokestose was close to that of 1kestose, mainly in the bottom portion, although its content was lower and the content did not increase at the end of storage except in the top portion during the last five days of storage (Fig. 2B). However at $20^{\circ} \mathrm{C}$, neokestose content of the top portion was significantly higher during storage, while no significant difference was observed between the portions at 4 and $10^{\circ} \mathrm{C}$ during storage.

Nystose content variation was close to that of sucrose where little variation was observed at 4 and $10^{\circ} \mathrm{C}$, while at $20^{\circ} \mathrm{C}$, content in the top and middle portions increased significantly during the last 3 days of storage (Fig. 2C).

During storage, variation of invertase activity was similar at 4 and $10^{\circ} \mathrm{C}$ although this activity was slightly lower at $10^{\circ} \mathrm{C}$ (Fig. 3A). This activity ranged between 1.80 and $0.67 \mathrm{U} / \mathrm{g} \mathrm{FW}$ after 1 day of storage and decreased one fold after 2 weeks. At $20^{\circ} \mathrm{C}$, invertase activity decreased slightly in the middle and bottom portions, while in top portion the activity increased sharply from 1.46 to 3.25 $\mathrm{U} / \mathrm{g}$ FW after 2 days, before decreasing abruptly to 0.36 U/g FW after 1 week's storage. Its activity remained stable during the last week of storage. This sharp increase and decrease in the top portion was caused by the high activity of the elongation zone of the spears and the high demand for substrate.

The activity of 1-KHE enzyme was very similar to that of invertase activity (Fig. 3B). At 4 and $10^{\circ} \mathrm{C}$, activity varied slightly although the final values were low when compared to those observed at the beginning of storage. At $20^{\circ} \mathrm{C}$, little variation was observed in the middle and bottom portions, while in the top portion activity in- creased by three fold, from 0.32 to $0.97 \mathrm{U} / \mathrm{g} F W$, after 2 days, before decreasing sharply, to $0.41 \mathrm{U} / \mathrm{g} \mathrm{FW}$, after 6 days. The activity of 1-KHE remained stable although an increase was observed during the last 2 days of storage.

The activity of 1-SST, which is the first enzyme involved in FOS biosynthesis, did not show any variation in the bottom portion during the storage period at any of the three temperatures (Fig. 4A). In the middle and top portions, 1-SST activity increased during the first two or three days, then decreased and remained stable during the second week. Surprisingly, the pattern of 1-SST was similar to that of 1-kestose hydrolyzing activity, and this suggests that a balance in released 1-kestose is maintained in the top portion in order to avoid accumulation of the reaction products of 1-KHE, i.e. sucrose and fructose. Thus, it seems that 1-kestose plays a close metabolic role to sucrose by maintaining a specific osmotic pressure along the spear. On the other hand, these patterns demonstrate well the high catabolic activities occurring in the top portion which is constituted mainly by meristematic cells and this elongating part of the spear needs a large amount of substrate.

The activity of the synthesizing enzyme 1-FFT was high in the top portion and low in bottom portion at the three temperatures (Fig. 4B). However, this activity was high at $4{ }^{\circ} \mathrm{C}$ while the lowest activity was observed at 20 ${ }^{\circ} \mathrm{C}$. In the middle and bottom portions, 1-FFT activity changed slightly, while in the top portion this activity decreased during storage time and this decrease was more apparent at 4 and $10^{\circ} \mathrm{C}$. The low activity observed at $20^{\circ} \mathrm{C}$ is probably due to the high catabolism of 1-kestose and
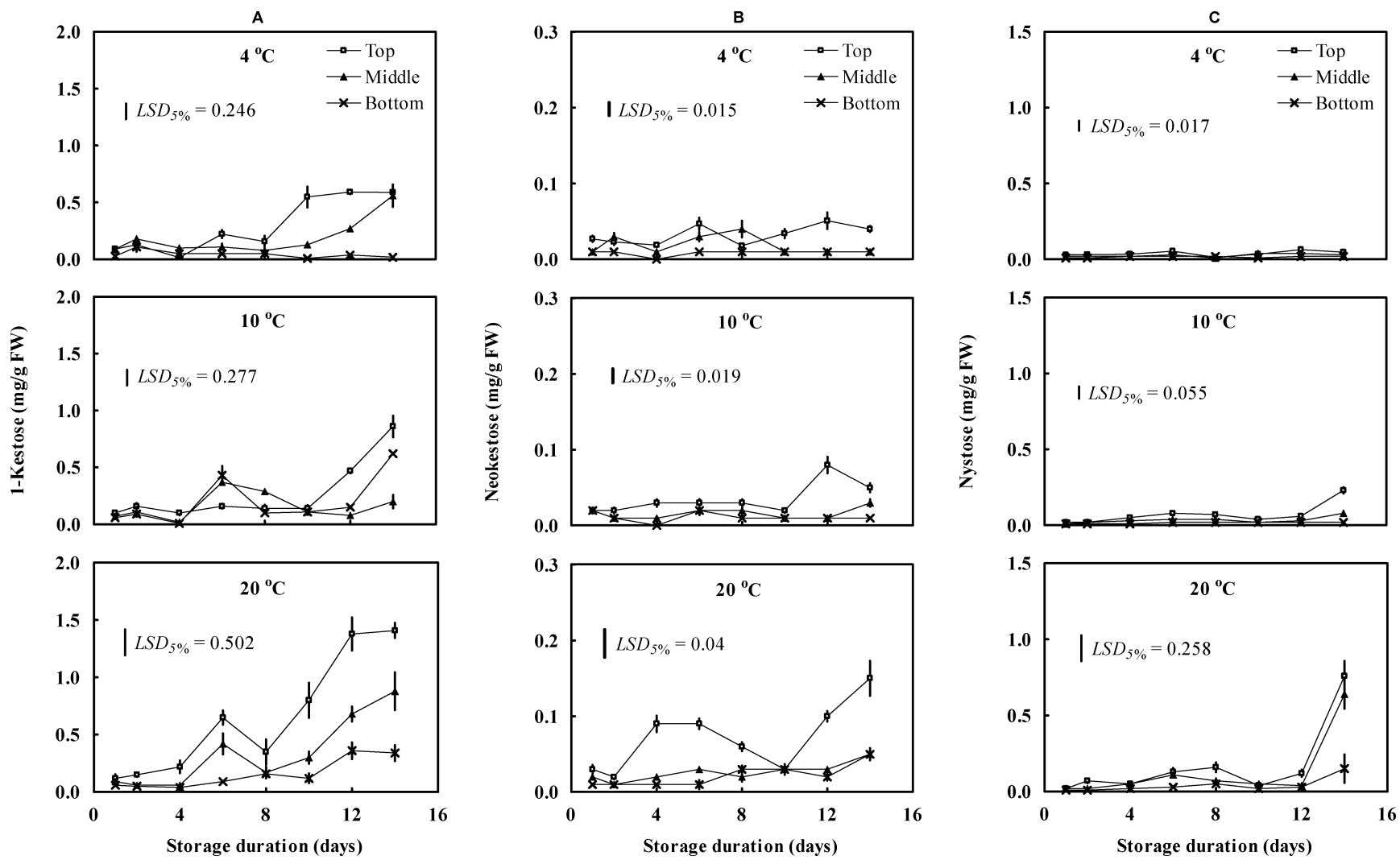

Fig. 2. Variation of 1-kestose (A), neokestose (B) and nystose (C) contents in the top, middle and bottom portions of asparagus spears stored at different temperatures.

Vertical bars represent $\pm \mathrm{SD}$ of $n=6$ and LSD was calculated at $p=0.05$. 

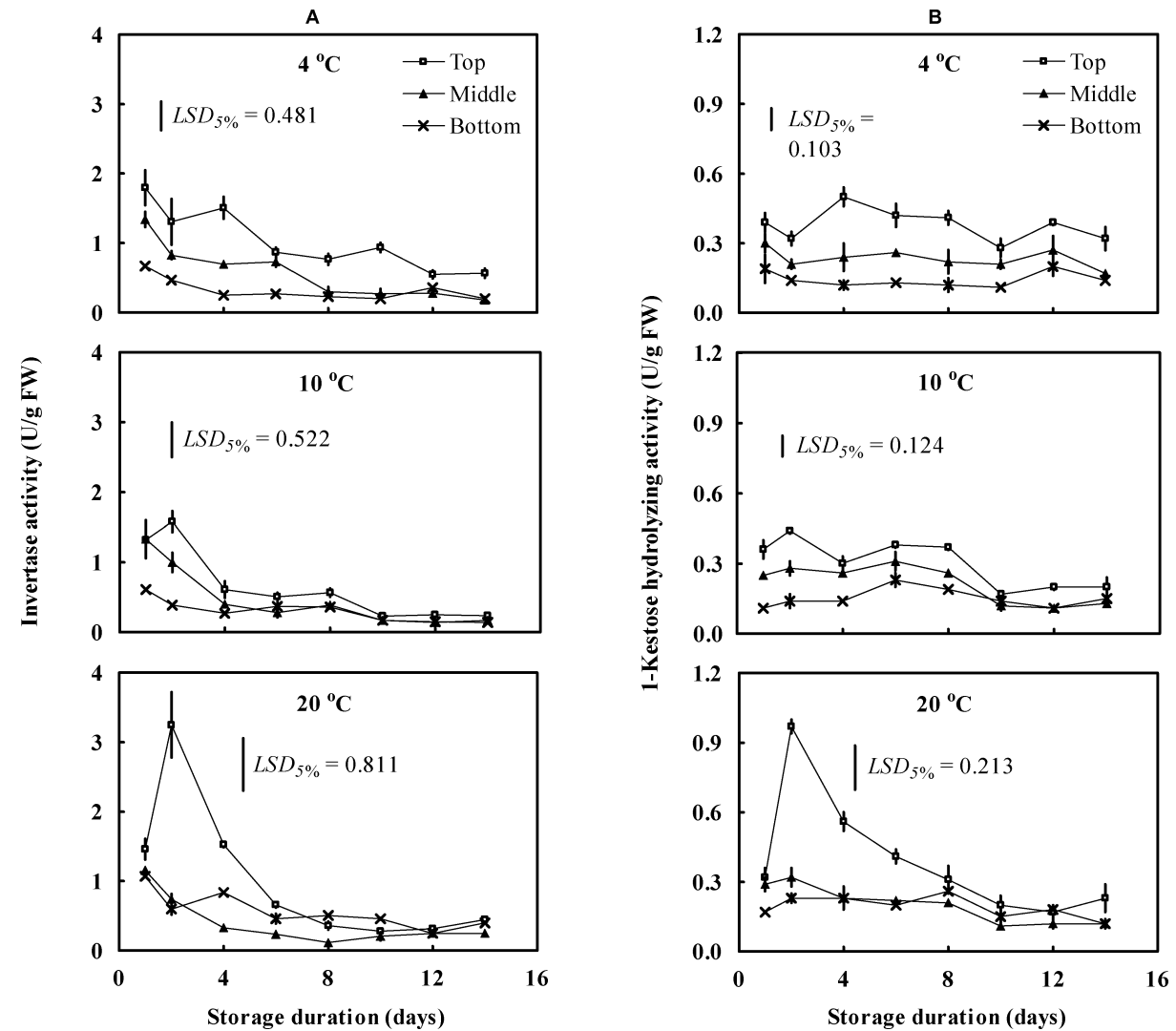

Fig. 3. Variation of invertase (A) and 1-KHE (B) in the top, middle and bottom portions of asparagus spears stored at different temperatures.

Vertical bars represent \pm SD of $n=6$ and LSD was calculated at $p=0.05$.
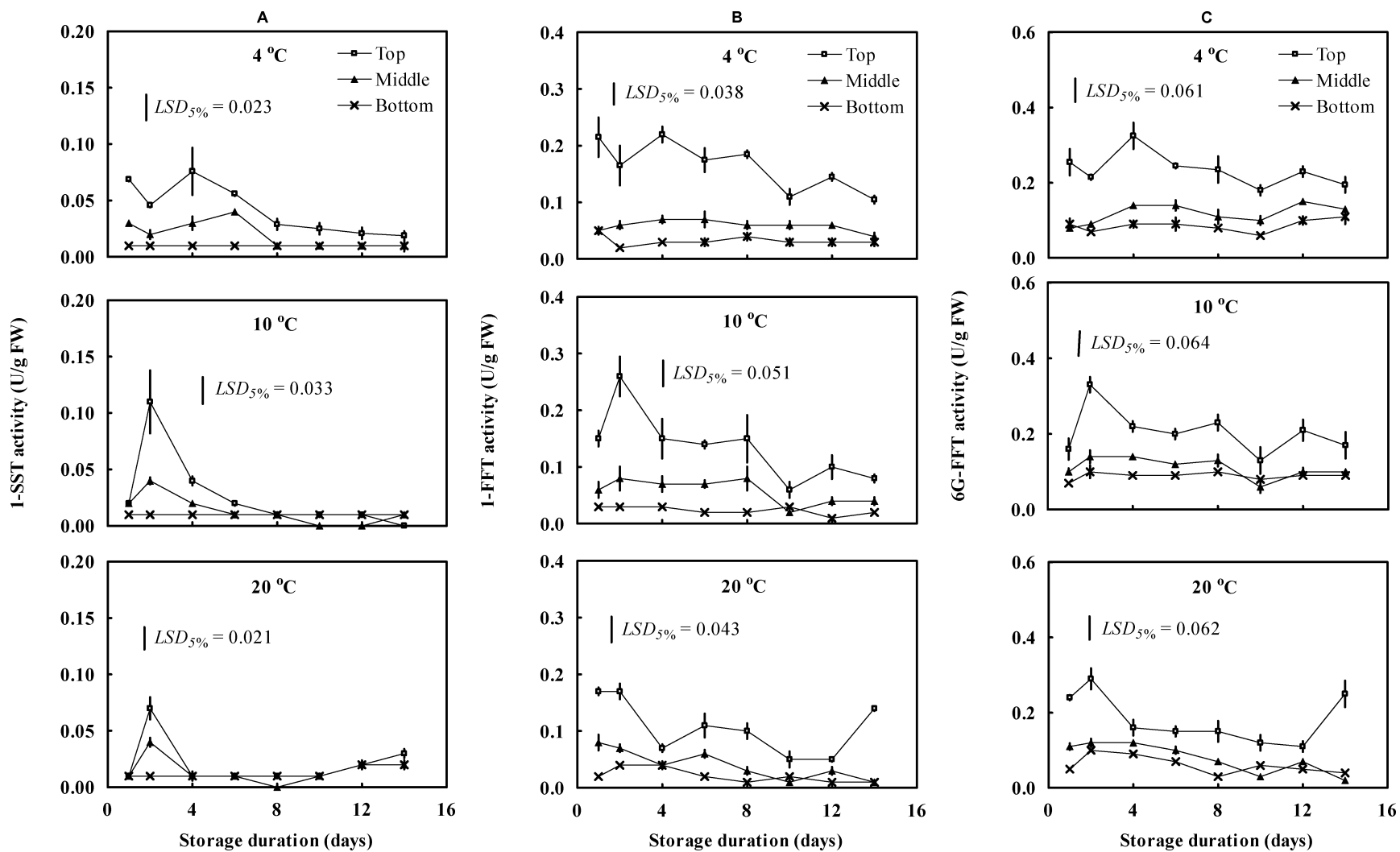

Fig. 4. Variation of 1-SST (A), 1-FFT (B) and 6G-FFT (C) activities in the top, middle and bottom portions of asparagus spears stored at different temperatures.

Vertical bars represent $\pm \mathrm{SD}$ of $n=6$ and LSD was calculated at $p=0.05$. 
lower availability of substrate, but at low temperature we noted low catabolic activity and thus greater availability of substrate, from which the enzyme synthesizes nystose.

The variation of the activity of 6G-FFT was similar to that of 1-FFT; however, its level was higher (Fig. 4C). The highest activity was observed in the top portion at 4 ${ }^{\circ} \mathrm{C}$, while the lowest activity was observed in the middle and bottom portions. Similarly, we noted a difference between the top and other two portions, and this difference was more significant at 4 and $10^{\circ} \mathrm{C}$.

The 6G-FFT to 1-FFT activity ratio was estimated, and the values found were similar and temperature indepen- dent. At $4{ }^{\circ} \mathrm{C}$, the ratios were $1.5,2.1$ and 3.1 in the top, middle and bottom portions, respectively. At $10^{\circ} \mathrm{C}$, the respective values were $1.7,2.2$ and 4.1 , while at $20^{\circ} \mathrm{C}$ they were $1.8,2.3$ and 3.1. Indeed, the ratio $6 \mathrm{G}-\mathrm{FFT}$ to $1-\mathrm{FF}$ expresses the relative activity of 6G-FFT, which uses only linear fructooligosaccharide polymers, while 1-FFT uses both linear and branched (Fig. 5). These ratios demonstrate well the high activity of the 6G-FFT compared to 1FFT and this explain well why the content of 1-kestose is high compared with the content of neokestose and nystose. Thus, 6G-FFT even high relatively, tends to favor the accumulation of 1-kestose rather than exhausting

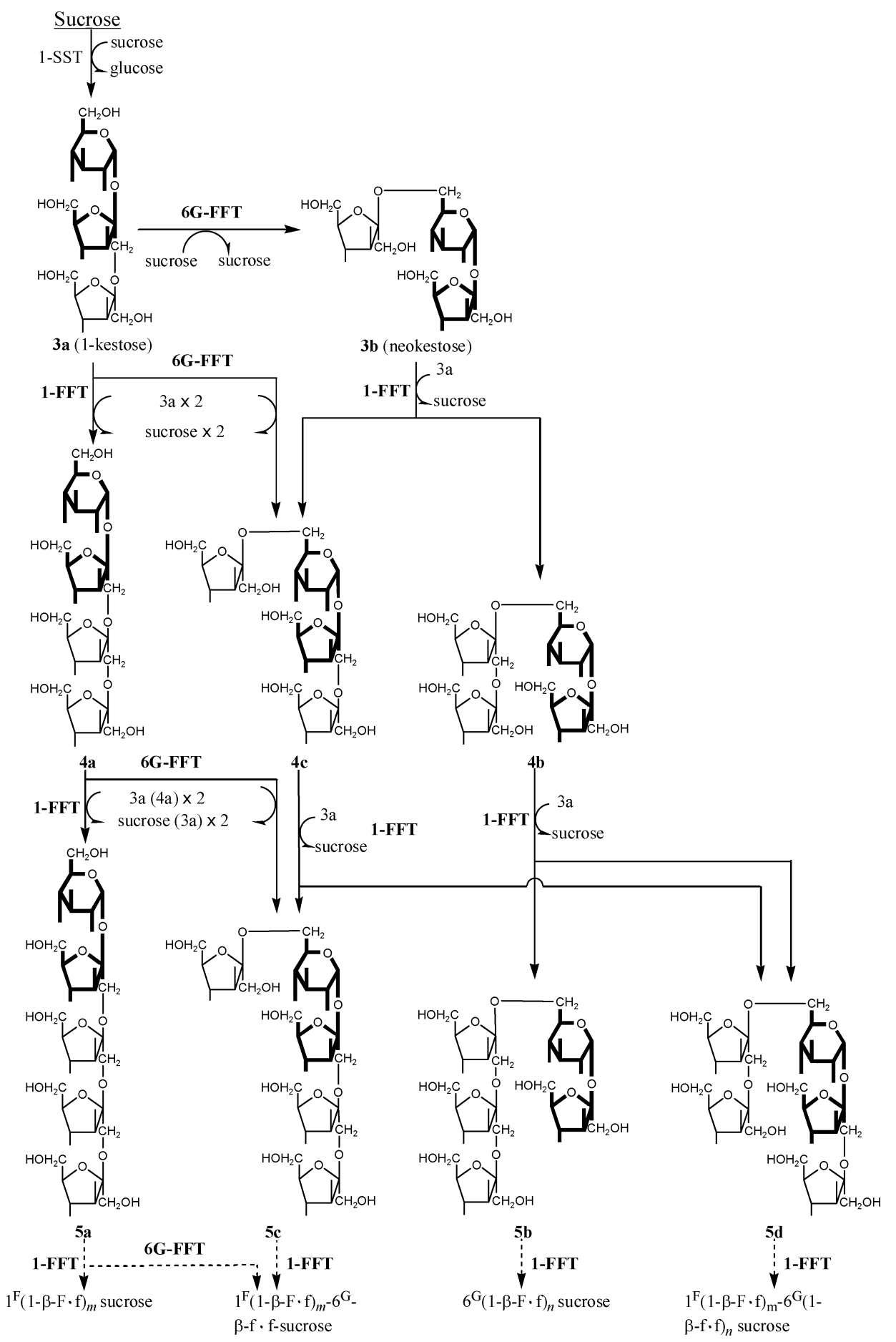

Fig. 5. Pathway of enzymatic biosynthesis of fructooligosaccharides in Lilliaceous plants. ${ }^{12}$

1-SST, sucrose: sucrose 1-fructosyltransferase; 1-FFT, fructan: fructan 1-fructosyltransferase; 6G-FFT, fructan: fructan $6^{\mathrm{G}}$-fructosyltransferase. 
this saccharide.

\section{DISCUSSION}

The carbohydrate content of asparagus roots and stems during growing has been subject of an extensive literature, while few studies have reported their content and variartion during storage. Little has also been reported on the carbohydrate content of different portions of the spears, and to our knowledge no data on the presence of fructooligosaccharides (FOS) are available.

Previous studies have reported that glucose, fructose and sucrose constitute the major part of carbohydrate in asparagus spears, although small amounts of 1-kestose and nystose have been detected ${ }^{19)}$ and these decreased during storage particularly during the first three days. ${ }^{5,20)}$ Bhowmik et al. ${ }^{21)}$ also noted that total sugar content was higher in the bottom portions than in the top portions. Hurst et $a{ }^{4}{ }^{4)}$ reported that glucose, fructose and sucrose levels in the top portions of green asparagus were higher in short spears than in long spears, while their levels were higher in the bottom portions than in top portions. This gradient from the bottom to the top was previously reported by Lill et al. ${ }^{3)}$ The low contents of reducing sugars observed in the top portions is the result of intense and extensive metabolic changes and spear elongation, which are linked to the high respiration rate during the first days of storage ${ }^{5,22)}$ and the length development of the spears. ${ }^{23)}$ McKenzie et al. $^{24)}$ also reported that glucose content decreased after one day of storage but increased later, while sucrose content did not change significantly during four days' storage. On the other hand, the low content observed in the top portion results from the lower level of sucrose during the growth stage than during the young or mature stages of the plants. ${ }^{25)}$ Guo et al. ${ }^{26)}$ found that sucrose content was slightly lower during developmental stages (10 and $20 \mathrm{~cm}$ in length). The authors also reported that hexose contents in the lower portions were higher than those in the top portions and tips. This pattern is strongly linked to its central role in carbohydrate metabolism and its relationship with the main substrate of invertase, 1-SST and 1-FFT. This pattern also demonstrates its role in maintaining osmotic pressure in the different portions of the spears because no significant difference was observed between the portions during storage except the last week at $10^{\circ} \mathrm{C}$.

There is no referenced data on the presence of short fructooligosaccharides (sFOS) in asparagus spears but extensive reports on their presence in asparagus roots. Because the carbon source is exported during this process, the slight presence of sFOS could be due to their transport through the sucrose gradient. This suggestion is well supported by the activity of 1-SST, which is weak during the last days of storage, while the activities of 1-FFT and 6GFFT are slightly higher. In fact, there is probably no initiation of FOS biosynthesis at this stage but only an elongation of pre-existent substrate (1-kestose), while this initiation starts from sucrose and 1-SST.

Invertase activity was also higher in the top portions because of this high metabolic change and the difference observed among the three temperatures is due the demand for substrate and energy which is high at $20^{\circ} \mathrm{C}$ and low at low temperatures. Bhowmik et al. ${ }^{27)}$ reported similar results and noted that soluble invertase activity was two fold higher in the top portions than in the bottom portions. Hurst et al. ${ }^{4)}$ noted that the activity of neutral invertase in the middle portions was slightly higher, but that activity in the top portions was higher than in bottom portions. Previous studies also reported that invertase decreased during storage.

The activity of the kestose-hydrolase was recently highlighted in onion (1-kestose hydrolase) $)^{28)}$ and wheat (6kestose hydrolase). ${ }^{29)}$ The recent finding of these two highly specialized enzymes is probably behind the lack of their studies in vegetable crops, mainly the liliaceous.

Surprisingly, the activities of FOS synthesizingenzymes have not been reported, either. Although these activities are high during root growth and are essential in the carbohydrate reserve of the underground organ of the plant, they also have a role during the postharvest life of vegetables. The most admitted hypothesis concerning this biosynthesis activity during postharvest life suggests that synthesizing enzymes play in fact a regulating role for sFOS and sucrose levels in the tissues. They maintain a balance, avoiding accumulation of substrates, mainly sucrose, which could inhibit the hydrolyzing enzymes and the increase of the osmotic pressure. Moreover, regardless of the physiological state of plants, there is a continuous metabolic activity; however, this activity is diverted towards a specific balance, depending upon the need of the physiological and developmental stages.

From the results we conclude the sugar contents of asparagus spears varied along the spears from the bottom to the top in a decreasing gradient. Contents declined during storage and this decline was particularly evident in the spear tips (top portion). Enzyme activities, both hydrolyzing and synthesizing, showed a balance by maintaining stable levels of glucose and sucrose which are considered as indicator molecules in plants, providing information on carbohydrate status. There is evidence that decline in the sugar contents of the top portion triggers deterioration of the spears by the loss of the turgor. This process is visible at first in the top portion which is typically the first part of the spear to show signs of quality deterioration.

Control of hydrolyzing enzymes, mainly invertase, by reducing their activities could maintain high level of sugars and extend the shelf-life of asparagus spears. The presence of higher levels of 1-kestose and nystose than those observed could maintain the activities of synthesizing enzymes, and reduces the activity of invertase. Further investigations are needed to show how these sFOS might influence carbohydrate metabolism in asparagus spears.

This work was supported by a grant from the University of Rakuno Gakuen.

\section{REFERENCES}

1 ) W.J. Lipton: Postharvest biology of fresh asparagus. in Horticultural Reviews, Vol. 12, J. Janick, ed., Timber Press, Portland, pp. 69-149 (1990).

2 ) A.K.M.S. Alam, T. Matsui and T. Ikeuchi: Changes in acid in- 
vertase activity and sugar distribution in asparagus spears harvested in autumn. Jpn. J. Trop. Agric., 42, 257-262 (1998).

3 ) R.E. Lill, G.A. King and E.M. O’ Donoghue: Physiological changes in asparagus spears immediately after harvest. Sci. Hortic., 44, 191-199 (1990).

4 ) P.L. Hurst, L.M. Hyndman and P.J. Hannan: Sucrose synthase, invertases, and sugars in growing asparagus spears. NZ. $J$. Crop Hortic. Sci., 21, 331-336 (1993).

5 ) D.E. Irving and P.L. Hurst: Respiration, soluble carbohydrates and enzymes of carbohydrate metabolism in tips of harvested asparagus spears. Plant Sci., 94, 89-97 (1993).

6 ) G.A. King, P.L. Hurst, D.E. Irving and R.E. Lill: Recent advances in the postharvest physiology, storage and handling of green asparagus. Postharvest News Info., 4, 85N-89N (1993).

7 ) N. Shiomi, J. Yamada and M. Izawa: Isolation and identification of fructooligosaccharides in roots of asparagus (Asparagus officinalis L.). Agric. Biol. Chem., 40, 567-575 (1976).

8 ) N. Shiomi, J. Yamada and M. Izawa: A novel pentasaccharide in the roots of asparagus (Asparagus officinalis L.). Agric. Biol. Chem. , 43, 1375-1377 (1979).

9 ) N. Shiomi: Two novel hexasaccharides from the roots of Asparagus officinalis. Phytochemistry, 20, 2581-2583 (1981).

10) N. Shiomi, S. Onodera, N.J. Chatterton and P.A. Harrison: Separation of fructooligosaccharide isomers by anion-exchange chromatography. Agric. Biol. Chem., 55, 1427-1428 (1991).

11) N. Shiomi: Structure of fructo-polysaccharide (asparagosin) from roots of asparagus (Asparagus officinalis L.). New Phytol., 123, 263-270 (1993).

12) N. Shiomi: Properties of fructosyltransferases involved in the synthesis of fructan in liliaceous plants. J. Plant Physiol., 134, $151-155$ (1989).

13) K. Ueno, S. Onodera, A. Kawakami, M. Yoshida and N. Shiomi: Molecular characterization and expression of a cDNA encoding fructan: fructan 6G-fructosyltransferase from asparagus (Asparagus officinalis). New Phytol., 165, 813-824 (2005).

14) N. Shiomi, N. Benkeblia, S. Onodera and M. Osaki: The metabolism of fructooligosaccharides in asparagus (Asparagus officinalis L.). in Recent Advances in Fructooligosaccharides Research, N. Shiomi, N. Benkeblia and S. Onodera, eds., Research Signpost Publisher, Kerala, pp. 213-230 (2007).

15) D.W. Brash, C.M. Chris, S. Wright and B.L. Bycroft: Shelflife of stored asparagus is strongly related to postharvest respiratory activity. Postharvest Biol. Technol., 5, 77-81 (1995).

16) G.A. King, K.G. Henderson, E.M. O’ Donoghue, W. Martin and R.E. Lill: Flavour and metabolic changes in asparagus during storage. Sci. Hortic., 36, 183-190 (1988).

17) N. Shiomi: Content of carbohydrate and activities of fructosyltransferase and invertase in asparagus roots during fructooligosaccharide- and fructopolysaccharide accumulating season. New Phytol., 122, 421-432 (1992).

18) H. Takeda, K. Sato, S. Kinoshita and H. Sasaki: Production of 1-kestose by Scopulariopsis brevicaulis. J. Ferment. Bioeng., 77, 386-389 (1994).

19) N. Benkeblia, N. Yoshida, Y. Ooi, T. Nagamine, S. Onodera and N. Shiomi: Variations of carbohydrate content and invertase activity in green and white asparagus spears: Effects of spear length and portion. Acta Hortic., (2007) in press.

20) M.J. Villanueva-Suárez, A. Redendo-Cuenca, M.D. RodríguezSevilla and M. De Las Heras-Martínez: Characterization of nonstarch polysaccharides content from different edible organs of some vegetables, determined by GC and HPLC: Comparative study. J. Agric. Food Chem., 51, 5950-5955 (2003).

21) P.K. Bhowmik, T. Matsui, T. Ikeuchi and H. Suzuki: Changes in storage quality and shelf life of green asparagus over an extended harvest season. Postharvest Biol. Technol., 26, 323-328 (2002).

22) P.P. Papadopoulou, A.S. Siomos and C.C. Dogras: Metabolism of etiolated and green asparagus before and after harvest. $J$. Hortic. Sci. Biotechnol., 76, 497-500 (2001).

23) R.E. Paull and N.J. Chen: Heat treatment prevents postharvest geotropic curvature of asparagus spears (Asparagus officinalis L.). Postharvest Biol. Technol., 16, 37-41 (1999).

24) M.J. McKenzie, L.A. Greer, J.A. Heyes and P.L. Hurst: Sugar metabolism and compartmentation in asparagus and broccoli during controlled atmosphere storage. Postharvest Biol. Technol., 32, 45-56 (2004).

25) H.A. Ross, H.V. Davies, I.R. Burch, R. Viola and D. McRae: Developmental changes in carbohydrate content and sucrose degrading enzymes in tuberising stolons of potato (Solanum tuberosum). Physiol. Plant., 90, 748-756 (1994).

26) J. Guo, W.A. Jermyn and M.H. Turnbull: Carbon metabolism in developing spears of two asparagus (Asparagus officinalis) cultivars with contrasting yield. Aust. J. Plant Physiol., 28, 1013-1021 (2001)

27) P.K. Bhowmik, T. Matsui, K. Kawada and H. Suzuki: Seasonal changes of asparagus spears in relation to enzyme activities and carbohydrate content. Sci. Hortic., 88, 1-9 (2001).

28) N. Benkeblia, S. Onodera and N. Shiomi: Variation in 1-fructoexohydrolase (1-FEH) and 1-kestose hydrolysing (1-KH) activities, and fructo-oligosaccharides (FOS) status in onion bulbs. Influence of temperature and storage time. J. Sci. Food Agric., 85, 227-234 (2005).

29) W. Van den Ende, M. Yoshida, S. Clerens, R. Vergauwen and A. Kawakami: Cloning, characterization and functional analysis of novel 6-kestose exohydrolases (6-KEHs) from wheat (Triticum aestivum). New Phytol., 166, 917-932 (2005).

\section{グリーンアスパラガス若茎貯蔵時における糖類, フルクトオリゴ糖類の含量およびインベルターゼ, 1-KHE, 1-SST, 1-FFT, 6G-FFT 活性 : 温度および部位の影響}

塩見徳夫 ${ }^{1}$, Noureddine Benkeblia ${ }^{1}$, 小野寺秀一 ${ }^{1}$, 大森俊馬 ${ }^{1}$ 高橋夏子 ${ }^{1}$, 藤島雅基 ${ }^{1}$, 義平大樹 ${ }^{2}$, 小坂進一 ${ }^{2}$ 酪農学園大学酪農学研究科 ${ }^{1}$ 食品栄養科学専攻, 2 酪農学専攻

(069-8501 江別市文京台緑町 582)

アスパラガス若菱に, グルコース, フルクトース, シュクロースの他に少量の1-ケストース，ニストースな ど短鎖のフルクトオリゴ糖が含まれていることをすでに 報告した。本研究ではグリーンアスパラガス若茎を異 なった温度条件下で貯蔵したときのそれぞれの糖量およ び関連合成・分解酵素活性の推移を部位別に調べた。グ リーンアスパラガス若茥を, 温度 $4 \pm 0.1{ }^{\circ} \mathrm{C} \cdot$ 湿度 $65 \pm 1 \%$, $10 \pm 0.1^{\circ} \mathrm{C} \cdot 55 \pm 1 \%, 20^{\circ} \mathrm{C} \cdot 50 \%$ の各条件で 14 日間貯蔵し た. 各条件で保存後, 上・ 中.下部に分けて細切し, エ タノール抽出を行い糖含量を定量した。また，関連酵素 についても上・中・下部に分け，インベルターゼ活性, 1-KHE 活性, 1-SST 活性, 1-FFT 活性, 6G-FFT 活性を測 定した。グルコースおよびフルクトース含量は，貯蔵中 に有意に変化したが，シュクロース含量については変化 がみられなかった (Fig. 1A，1B)。また，1-ケストースお よびニストースについては，貯蔵期間の後期で増加し， 特に $20^{\circ} \mathrm{C}$ で顕著であった (Fig. $2 \mathrm{~A} ， 2 \mathrm{C}$ ). インベルター ゼ活性については, $4^{\circ} \mathrm{C}$ と $10^{\circ} \mathrm{C}$ で類似し， $20^{\circ} \mathrm{C}$ では貯蔵 2 日目で増加し，その後減少した (Fig. 3A). また，1KHE 活性はインベルターゼ活性と類似したパターンを示 した(Fig. 3B). 1-SST 活性は, 上・中部の貯蔵初期に増加 したが，下部では貯蔵中ほとんど変化しなかった (Fig. 4A). 1-FFT 活性は上部で高く, 貯蔵の後期にかけて 減少したが，中・下部ではほとんど変化がみられなかっ た (Fig. 4B). 6G-FFT 活性の変動パターンは1-FFT と類似 していたが6G-FFT 活性はより高く，また6G-FFT と 1FFTの比率は温度と無関係であることが確認された。以 上のことから，短鎖フルクトオリゴ糖と関連酵素は，ア スパラガス若茥において糖濃度が高くなった場合すみや かに低下させ，糖のバランスを調節するための役割を果 たしているものと推定される. 